\title{
Investigation of the Use of Old Railroad Ties (Fagus orientalis) and Citrus Branches (Orange Tree) in the Particleboard Industry
}

\begin{abstract}
Ali Hassanpoor Tichi *
Effects of two widely available and underutilized lignocellulosic materials on the mechanical and physical properties of particleboards were investigated in this work. The ratio of mixtures lignocellulosic flakes at four levels (100\% aspen wood), (50\% aspen wood: $25 \%$ citrus: $25 \%$ old railroad ties), (50\% aspen wood: $50 \%$ citrus), and (50\% aspen wood: $50 \%$ old railroad ties), and the percentage of resin in two levels (8 and 12\%) were considered as variable factors. The $100 \%$ aspen wood (Populus tremula) was mixed as a control board ( $100 \%$ aspen wood). Then the mechanical and physical properties of the samples including modulus of rupture, modulus of elasticity, internal bond, water absorption, and thickness swelling after $2 \mathrm{~h}$ and $24 \mathrm{~h}$ of immersion (EN 310-319) and fire resistance (ISO 11925-2) were measured. The results showed that with increasing poplar wood in mixtures, modulus of rupture, modulus of elasticity, internal bond increased, while water absorption and thickness swelling decreased. Also, in comparison with the control boards, the boards that were made by mixing $50 \%$ poplar and $50 \%$ citrus branches with $12 \%$ glue had the highest mechanical strength. The results also showed that increasing the amount of old railroad ties chips in mixing caused a significant decrease in the fire retardancy of the boards.
\end{abstract}

Keywords: Branches; Old railroad ties; Particleboard; Resin; Percentage; Modulus of rupture

Contact information: Department of Wood Industry, Technical and Vocational University (TVU), Tehran, Iran; *Corresponding author: hasanpoortichi@gmail.com

\section{INTRODUCTION}

Particleboard industries have a special emphasis on the use of waste and lumber, including low-consumption wood species, forest bark residues, and lignocellulosic waste from farms and garden trees. In this regard, identifying new lignocellulosic sources and investigating the possibility of using them to feed particleboard production units has a special priority, and the present research was carried out on this basis. One lignocellulosic material that has recently been considered is old railroad ties. Such lumber comes out from under the rails after 25 years and no longer has any special application in industry. Its volume reaches $180,000 \mathrm{~m}^{3} / \mathrm{yr}$. The amount of such wood is more than commercial species such as beech (Fagus orientalis) and hornbeam (Carpinus betulus), which are commonly used in fencing around gardens and agricultural lands. Old railroad ties typically are impregnated with oily preservatives (creosote). Another lignocellulosic material used in this study was citrus tree branches, whose annual production reaches 8,000 tons/yr according to the Organization of Agriculture Jihad Mazandaran (Deputy Minister of Planning and Economic Affairs of Jihad-e-Agriculture of Mazandaran). Limitation of wood resources and increasing market demand for particleboard in Iran motivates the use of various lignocellulosic resources such as agricultural waste, tree branches, and waste 
wood in particleboard. Utilization of such resources is viewed as a step towards job creation in addition to reducing deforestation. In addition to the type of wood raw material and lignocellulose, other factors such as the amount of resin, manufacturing conditions, and the quality of the wood particles themselves also affect the quality of the board. The studies were conducted to investigate the physical and mechanical properties of particleboard. Enayati and Bezaatipour (2000) studied the possibility of making particleboard from old railroad ties located in Karaj to Shirgah. After comparing the physical and mechanical properties of the boards, they found that the boards made of old railroad ties in the Karaj region had a higher physical and mechanical strength than boards made of old railroad ties located in Shirgah. Tabarsa et al. (2008) investigated the production of cement wood from old railroad ties. Variable factors in this study were the temperature $\left(60\right.$ and $\left.25^{\circ} \mathrm{C}\right)$ of the amount of calcium chloride (2, 5, and $7 \%$ dry weight) additive as a coupling material. Their results showed that the boards made at $25^{\circ} \mathrm{C}$ and using $7 \%$ additive had higher mechanical strength and less water absorption and thickness swelling. The effects of raw material density on the requirements of almond branches and poplar trees were tested with ureaformaldehyde resin (Doosthoseini 2002).

\section{EXPERIMENTAL}

\section{Composite Panel Production}

About $300 \mathrm{~kg}$ from each of the primary sources, including aspen wood (Populus tremula), old railroad ties (Fagus orientalis), and citrus branches (orange tree) were prepared. For this purpose, old railroad ties were collected from Shirgah Traverse Saturation Factory. Citrus branches and poplar wood were obtained from the gardens of Babol city and transferred to the laboratory of Alborz Research Institute located in Karaj (Fig. 1).

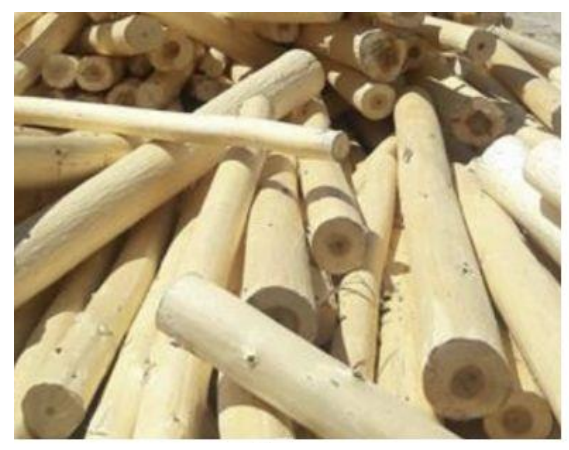

A

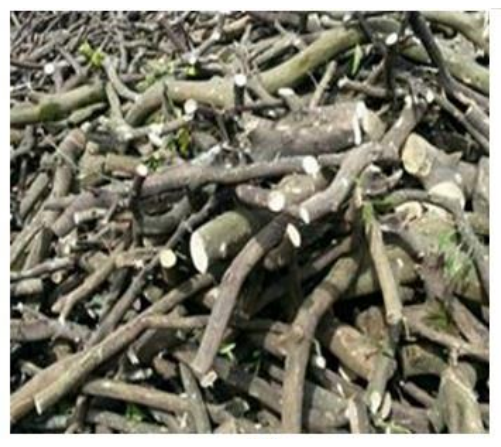

B

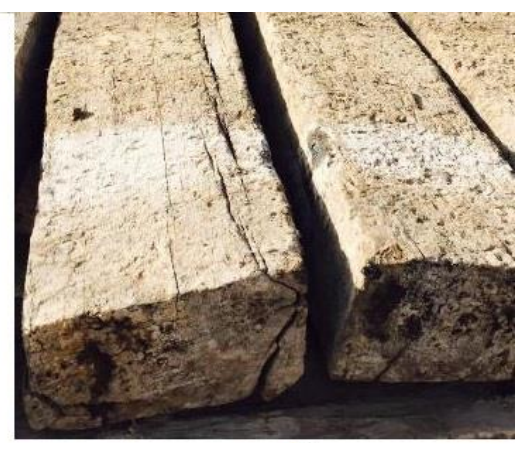

C

Fig. 1. Lignocellulosic materials used in this research: $(A)$ aspen wood, $(B)$ citrus branch, and (C) old railroad ties

The raw material was processed using a roller shredder and immediately turned into wood material suitable for particleboard using a ring mill. After removing very fine and very big wood chips that were not suitable for making particleboard, the moisture content of the particleboard was reduced to $1 \%$ through a laboratory dryer, and it was packed in moisture-resistant plastic bags and stored for making laboratory boards. For gluing the chips, a laboratory gluing machine was used. The glue solution along with the catalyst 
$\left(\mathrm{NH}_{4} \mathrm{Cl}\right)$ was thoroughly mixed with them. Subsequently, the cake (ingredients: lignocellulosic matrials and resin) from the mixing machine was poured uniformly into a $40 \times 40 \mathrm{~cm}$ wooden mold. After forming the particle cake, using a Bürkle-LA-160 (Bürkle, Stuttgart, Germany) laboratory press, the particle cake was pressed, and laboratory boards were made.

In this study, two factors, the amount of adhesive in two levels of 8 and $12 \%$ (based on the dry weight of wood chips) and the ratio of mixtures lignocellulosic flakes at four levels (100\% aspen wood), (50\% aspen wood: $25 \%$ citrus: $25 \%$ old railroad ties), $(50 \%$ aspen wood: $50 \%$ citrus), and (50\% aspen wood: $50 \%$ old railroad ties) were considered as variable factors in this study and other conditions including the type of the glue (ureaformaldehyde). Information of glue is given in Table 1. The following treatment conditions were kept constant in this work: press heat $\left(130{ }^{\circ} \mathrm{C}\right)$; board thickness $(16 \mathrm{~mm})$; pressure board weight $\left(0.7 \mathrm{~kg} / \mathrm{cm}^{3}\right)$; and press pressure $\left(30 \mathrm{~kg} / \mathrm{cm}^{2}\right)$. After the end of the press, to ensure uniformity of line moisture and balance the internal stresses, the boards were stored in the laboratory for 15 days. Mechanical properties [modulus of rupture (MOR) (EN 310 1993), modulus of elasticity (MOE) (EN 310 1993), and internal bond strength (IB) (EN 319 1993)] and physical properties [thickness swelling (TS) and water absorption (WA) (EN 317 1993)] were determined for the produced particleboards.

Table 1: Information of the Urea- Formaldehyde Resin

\begin{tabular}{|l|l|}
\hline Performances & Information \\
\hline solid content & $55.5(\%)$ \\
\hline free formaldehyde content & $39,77(\%)$ \\
\hline viscosity & $51.69(\mathrm{mPa} \cdot \mathrm{s})$ \\
\hline curing time & $90(\mathrm{~s})$ \\
\hline hot-press temperature & $130^{\circ} \mathrm{C}$ \\
\hline
\end{tabular}

The load and deflection were continuously recorded, and the data were used to calculate MOR, MOE, and IB based on Eqs. 1, 2, and 3,

$$
\begin{aligned}
& M O R=1.5 \times\left(F L / b d^{2}\right)(\mathrm{Mpa}) \\
& M O E=F L^{3} / 4 b d^{3} D \quad(\mathrm{Mpa}) \\
& I B=F / A \quad(\mathrm{Mpa})
\end{aligned}
$$

where $F$ is the maximum force $(\mathrm{N}), L$ is the span length $(\mathrm{mm}), b$ is the sample width (mm), $d$ is the sample thickness ( $\mathrm{mm}), D$ is the deflection, and $A$ is the sample cross section $\left(\mathrm{mm}^{2}\right)$.

\section{Physical Tests}

The effect of composite formulation on the water absorption (WA) and thickness swelling (TS) after 2 and $24 \mathrm{~h}$ immersion in water was determined in samples with the dimensions of $50 \mathrm{~mm} \times 50 \mathrm{~mm} \times 20 \mathrm{~mm}$ according to DIN EN 634-1 and 2 (DIN 1995). The sample was then soaked in distilled water for $2 \mathrm{~h}$ and $24 \mathrm{~h}$. Water absorption and TS were then calculated according to Eqs. 4 and 5,

$$
\begin{aligned}
& W A(\%)=\left[\left(W_{2}-W_{1}\right) / W_{1}\right] \times 100 \\
& T S=\left[\left(T_{2}-T_{1}\right) / T_{1}\right] \times 100
\end{aligned}
$$


where $W A$ is water absorption (\%), $W_{1}$ is dry mass before immersing $(\mathrm{g}), W_{2}$ is wet mass after each immersing $(\mathrm{g}), T S$ is thickness swelling $(\%), T_{1}$ is thickness before immersing $(\mathrm{g})$, and $T_{2}$ is thickness after each immersion $(\mathrm{g})$.

\section{Fire-Retardant Testing Apparatus}

The $150 \mathrm{~mm} \times 100 \mathrm{~mm} \times 20 \mathrm{~mm}$ boards were prepared according to ISO 11925 (2010) specifications for the fire resistance tests (Fig. 2). To test for the mass loss of the samples due to fire exposure the specimen was vertically mounted on a holder up-straight and exposed to a Bunsen-type burner (with an internal diameter of $11 \mathrm{~mm}$ ) held at $45^{\circ}$ to the surface of the specimen for $120 \mathrm{~s}$ in accordance with the method described by Esmailpour et al. (2017). The weight was measured before and after the test to measure the weight loss percent.

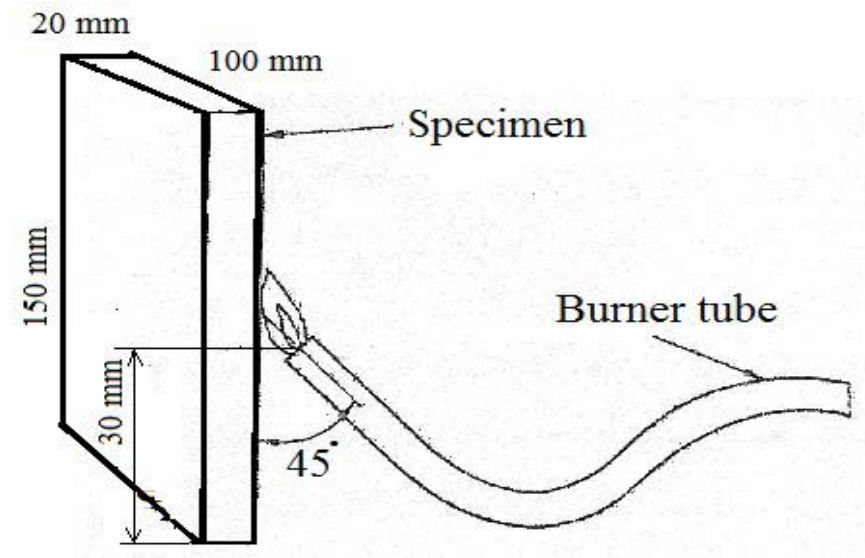

Fig. 2. Schematic of the fixed fire testing apparatus

\section{Statistical Analyses}

Statistical analyses were performed using Statistica software v.13 (Dell Inc., Round Rock, TX 2016). The obtained results were analyzed statistically, and an analysis of variance (ANOVA) was performed to determine the significance of the tested parameter. A Duncan's multiple range test (DMRT) was performed to compare treatment means.

\section{RESULTS AND DISCUSSION}

\section{Mechanical Properties}

The results from the mechanical testing are shown in Figs. 3, 4, and 5. The result indicated that increasing the old railroad ties chips in the mixture significantly decreased the MOR, MOE, and IB values of the particleboards. Adding aspen wood chips from 25\% to $50 \%$ significantly increased the MOR, MOE, and IB values of the particleboards. Similar results were reported by Enayati and Bezaatipour (2000). The highest MOR, MOE, and IB values were found in the control samples (100\% aspen wood) and the mixture of $(50 \%$ aspen wood $50 \%$ citrus branch) with $12 \%$ resin content. The lowest mechanical properties particleboard was in the mixture of (50\% citrous branch $50 \%$ old railroad ties) with $8 \%$ resin content (Figs. 3, 4, and 5). It is important to note that mechanical strength in boards that were made with $12 \%$ resin was significantly higher than panels made with $8 \%$ resin. This can be related to the positive effect of resin increment on mechanical strength (Kasim et al. 2001; Nacer et al. 2005; Pan et al. 2007; Ashori and Nourbakhsh 2008). Aspen wood 
is an excellent raw material for manufacturing particleboard. One of the reasons that caused the mechanical strength to improve with increasing aspen wood in the mix is its low density; aspen wood chips increased the compression ratio of the boards during pressing. This increased the mechanical strength of the boards. Decreasing mechanical properties with increasing old railroad ties chips in the mixture can be due to the oily properties of the chips, which made the adhesive not stick to the chip. The same results were reported in a previous study (Bazyar et al. 2011).

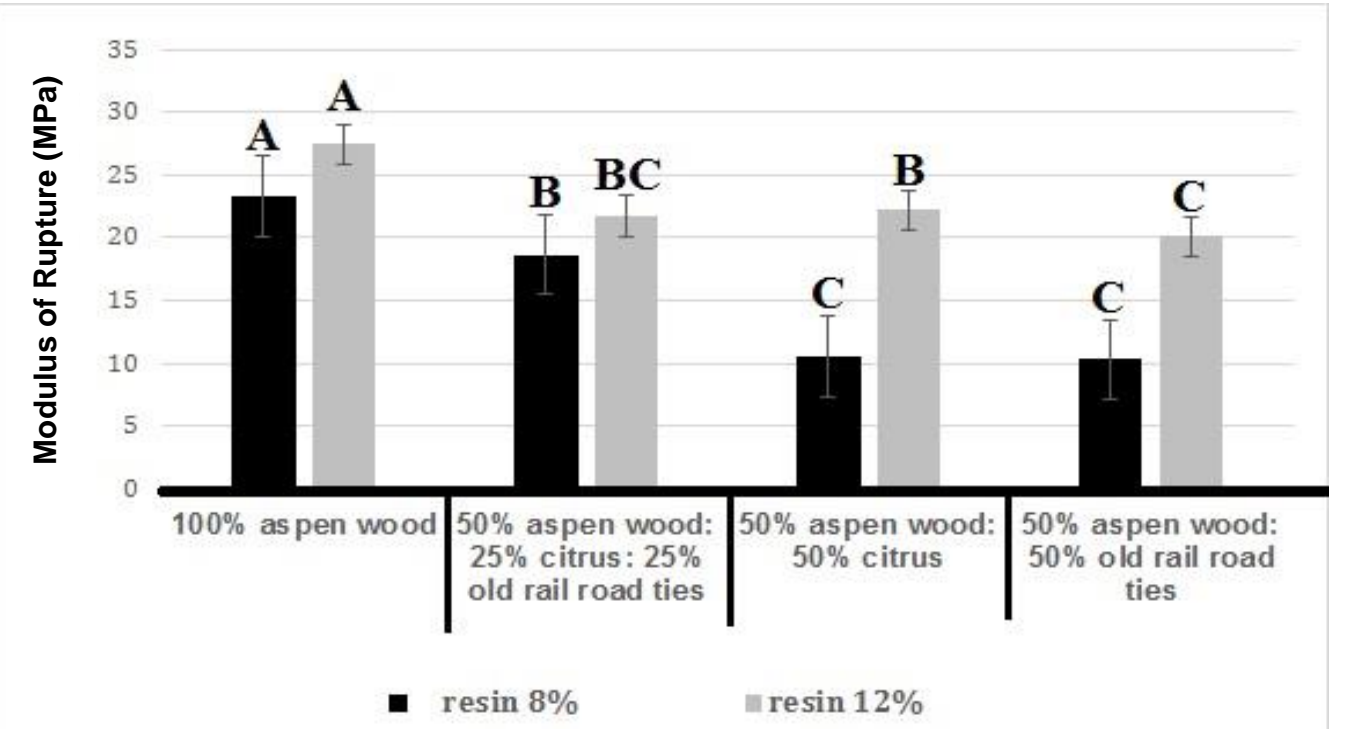

Fig. 3. MOR Strength particleboard made from aspen wood: citrous branch: old railroad ties contents (letters on each column indicate Duncan's grouping at the $99 \%$ level of confidence)

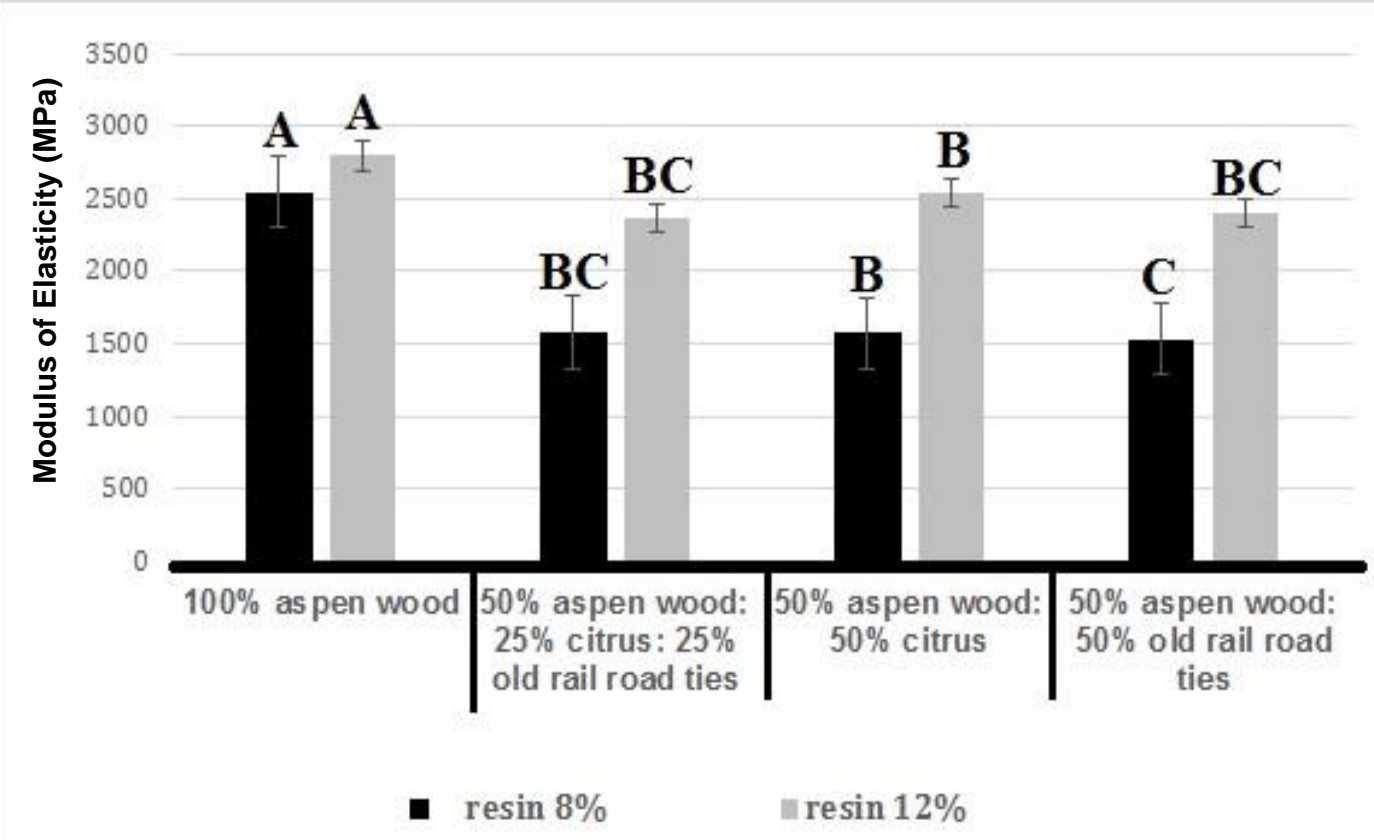

Fig. 4. MOE Strength particleboard made from aspen wood: citrous branch: old railroad ties contents (letters on each column indicate Duncan's grouping at the $99 \%$ level of confidence) 


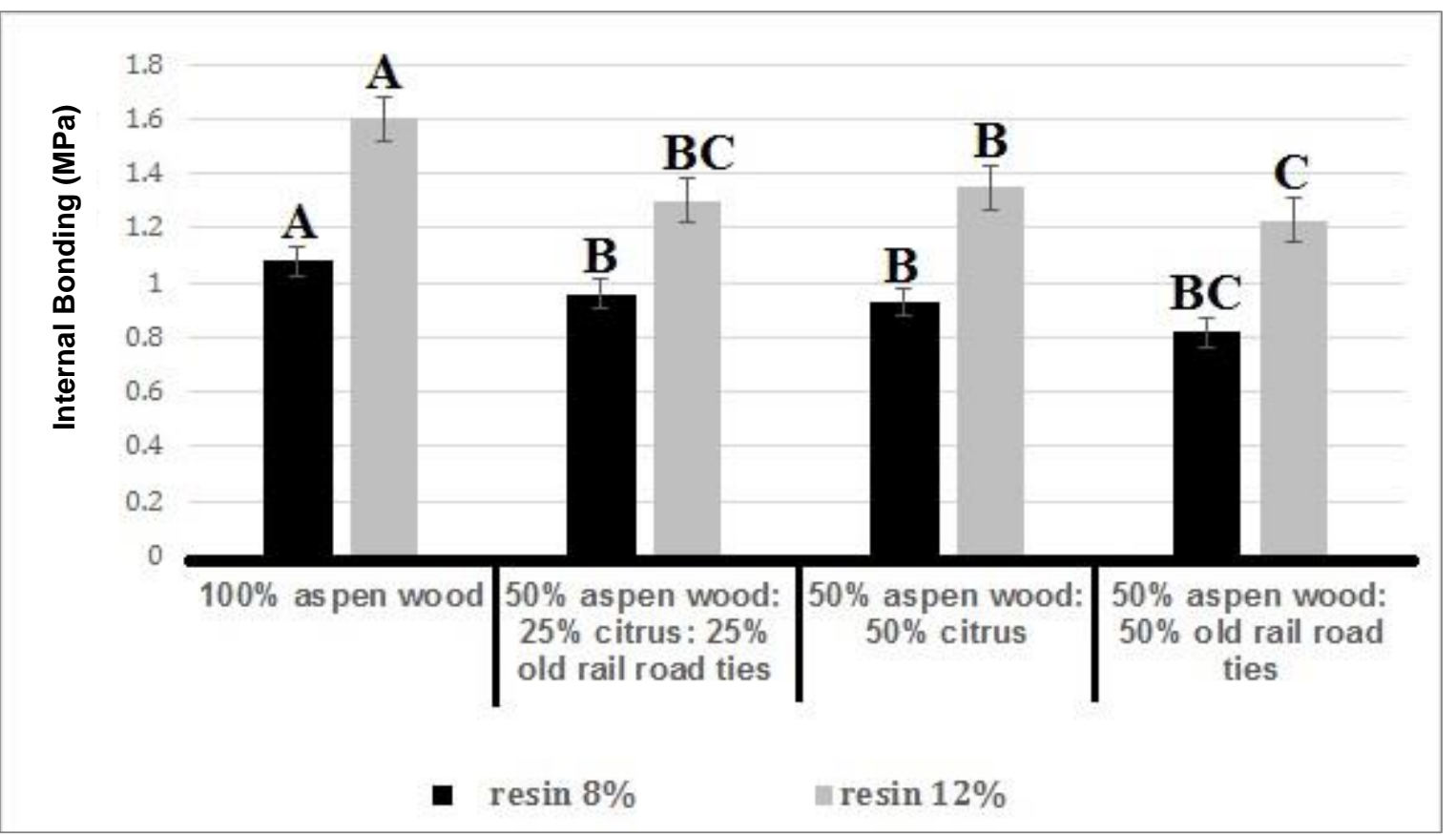

Fig. 5. IB Strength particleboard made from aspen wood: citrous branch: old railroad ties contents (letters on each column indicate Duncan's grouping at the $99 \%$ level of confidence)

\section{Physical Properties}

The physical properties of the panels evaluated were water absorption, thickness swelling after 2 and $24 \mathrm{~h}$ immersion in water, and fire resistance (mass loss). The results of these tests are presented in Figs. 6, 7, and 8.

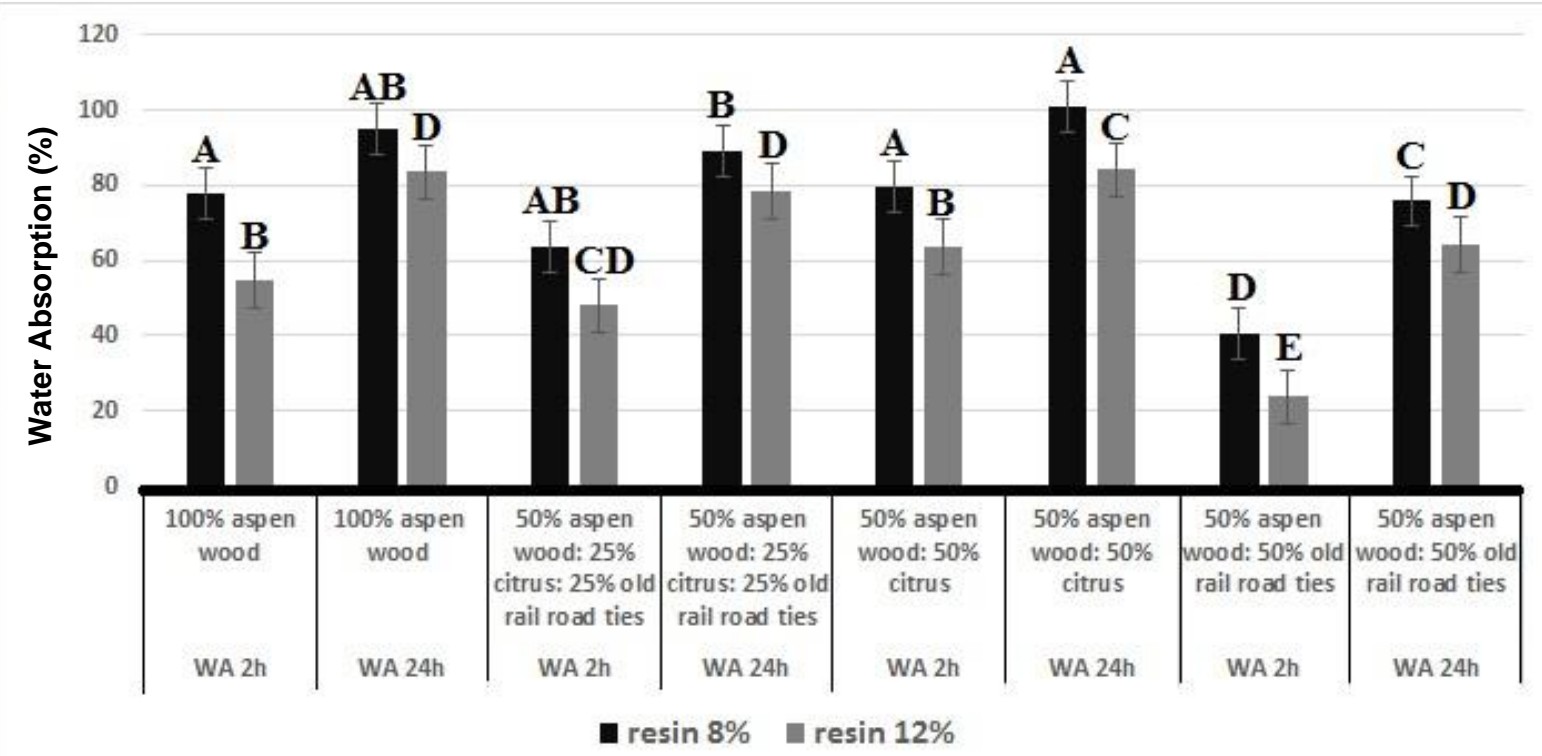

Fig. 6. Water absorption (\%) after 2 and $24 \mathrm{~h}$ particleboard made from aspen wood, citrous branch, and old railroad ties contents (letters on each column indicate Duncan's grouping at the $95 \%$ level of confidence) 


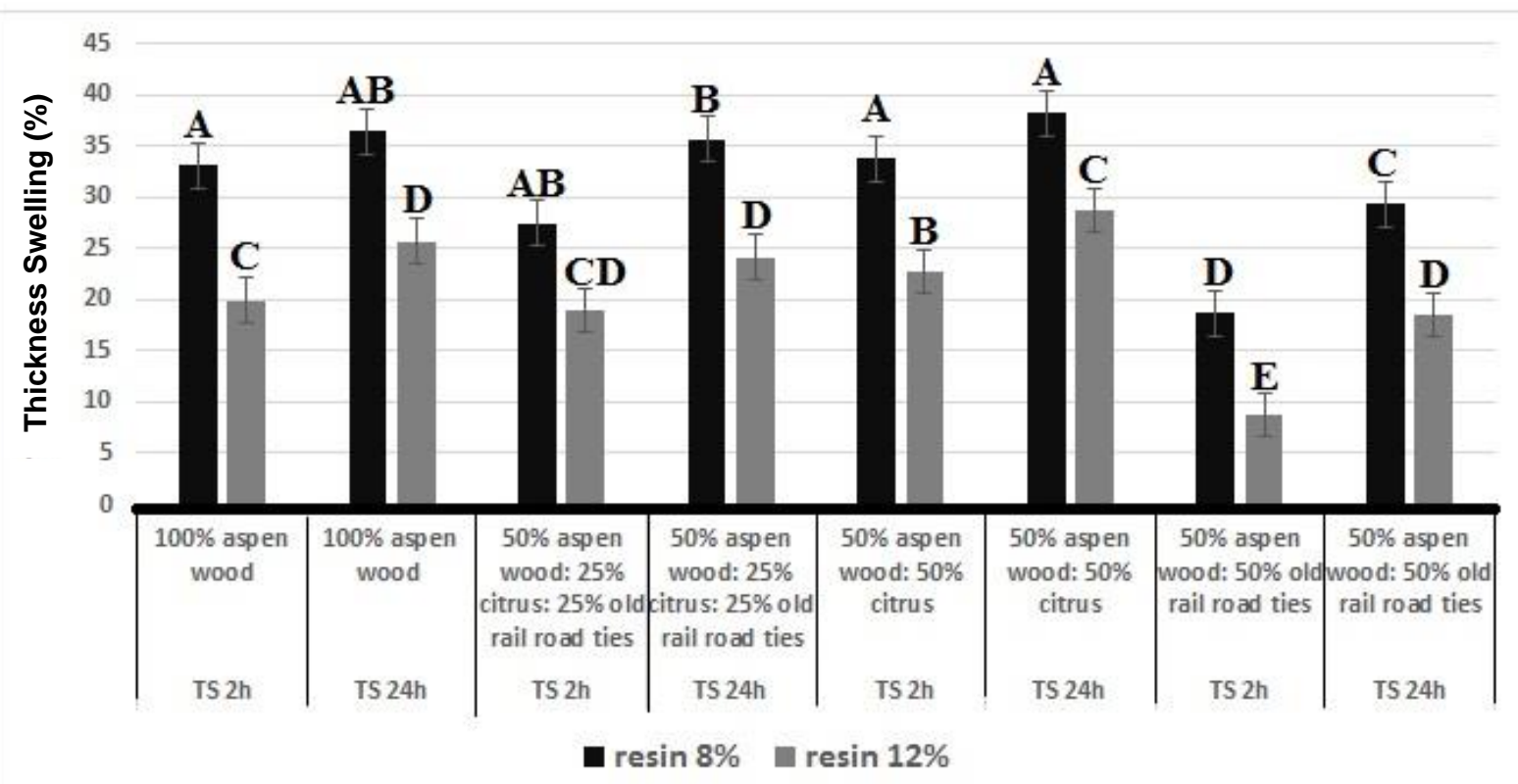

Fig. 7. Thickness swelling (\%) 2 and $24 \mathrm{~h}$ particleboard made from aspen wood, citrous branch, and old railroad ties contents (letters on each column indicate Duncan's grouping at the $95 \%$ level of confidence)

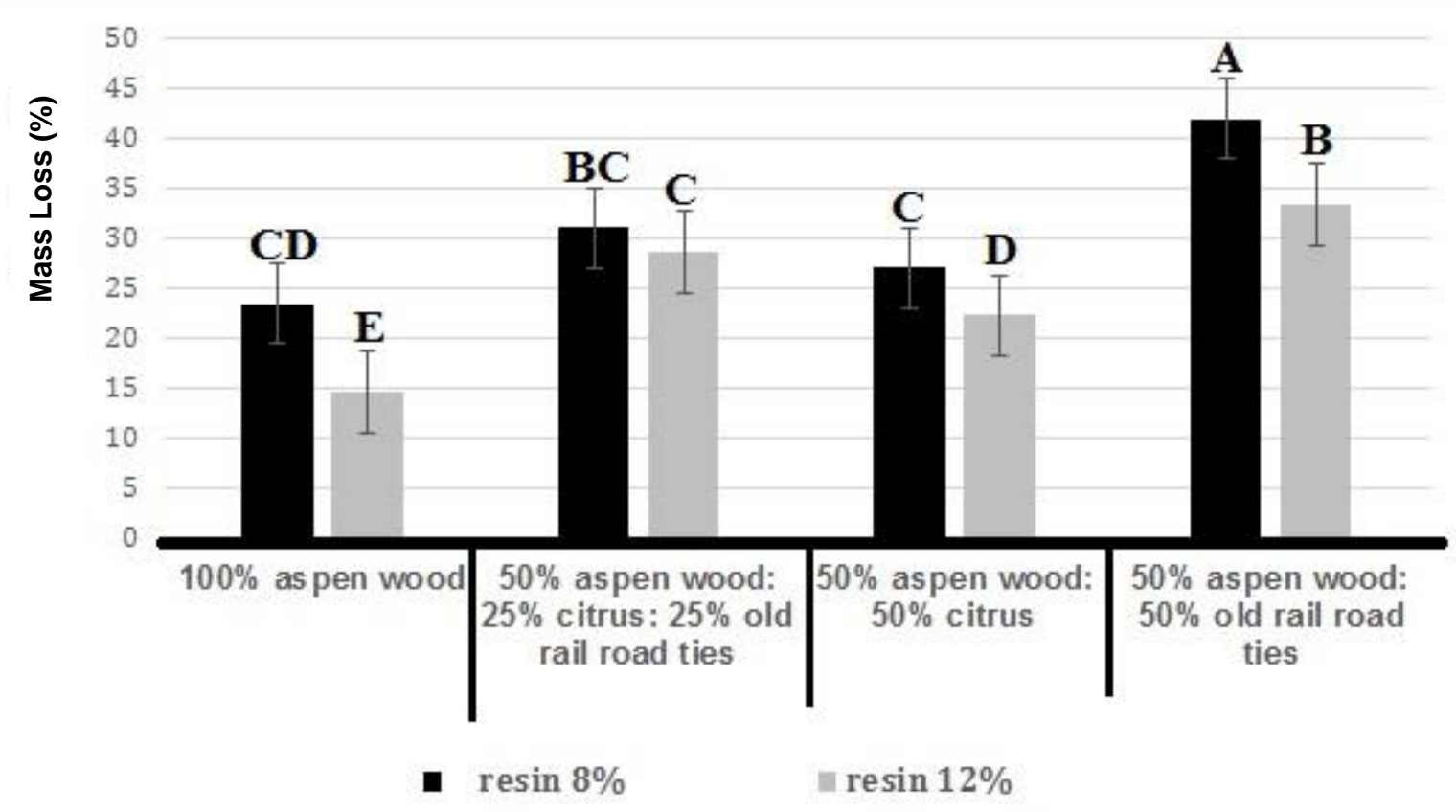

Fig. 8. Mass loss (\%) particleboard made from aspen wood, citrous branch, and old railroad ties contents (letters on each column indicate Duncan's grouping at the $99 \%$ level of confidence)

The water absorption and thickness swelling improved with each increment of the amount of old railroad ties in the panels. Also, results showed that increments of resin content from $8 \%$ to $12 \%$ had a significant effect on all physical properties of boards. With more resin, more bonding sites were made available, thereby increasing the dimensional stability of boards. The lowest water absorption and thickness swelling were observed in 
boards containing $50 \%$ aspen wood and $50 \%$ old railroad ties with $12 \%$ resin content (Figs. 6 and 7). It seems that the hydrophobic characteristic of creosote in waste wood can be related to the decrease of WA and TS in the samples that are made with more old railroad ties chips.

The highest water absorption and thickness swelling was found in the mixture of $50 \%$ aspen wood and 50\% citrus with $8 \%$ resin content (Figs. 6 and 7). The results indicated that the fire-retarding properties of the boards were decreased by the addition of old railroad ties chips in the mixture (Fig. 8). The lowest mass loss was observed in control samples (100\% aspen wood) and the mixture of $50 \%$ aspen wood and $50 \%$ citrus with $12 \%$ resin content (Fig. 8). Boards made of aspen wood have a higher density due to the higher compression coefficient during pressing. These boards have a high heat transfer, and their heat is not kept at a single point and is rapidly transferred to a point where it has less heat thus reducing the fireproof ability of boards and increasing their fire resistance. Because the wood chips made of old railroad ties were impregnated with an oily preservative, they burn quickly against a flame, which makes old railroad ties less resistant to fire.

\section{CONCLUSIONS}

1. Mechanical and physical properties of particleboards mixed with aspen wood, citrus branch, and old railroad ties were examined, and the results indicated that the reduced content of aspen wood chips and their replacement with either old railroad tie chips or citrus wood chips had a significant decreasing effect on modulus of rupture (MOR), modulus of elasticity (MOE), and internal bond strength (IB).

2. Due to its low density, aspen wood chips increased the compression ratio of the boards during pressing. This property increased the mechanical strength of the boards.

3. Old railroad ties significantly decrease water absorption and thickness swelling. hydrophobic characteristic of creosote in waste wood can be related to the decrease of WA and TS in the samples that are made with more old railroad ties chips.

4. Adding old railroad ties chips from $25 \%$ to $50 \%$ significantly decreased the fire resistance of the particleboards because the wood chips made of old railroad ties were impregnated with an oily preservative. This caused the chips to burn quickly against a flame.

\section{REFERENCES CITED}

Ashori, A. and Nourbakhsh, A. (2008). "Effect of press cycle time and resin content on physical and mechanical properties of particleboard panels made from underutilized low-quality raw material," Industrial Crops and Products 28, 225-230. DOI: 10.1016/j.indcrop.2008.02.015

Bazyar, B., Tichi, A. H., and Rangavar, H. (2011). "Particleboard made from fast growing aspen wood and old rail road ties," Australian Journal of Basic and Applied Sciences 5(8), 548-553.

Doosthoseini, K. (2002). "Fundamentals," in: Wood Composite Materials, Manufacturing, Applications, University of Tehran Press, Tehran, Iran. 
EN 310 (1993). "Wood-based panels, determination of modulus of elasticity in bending and bending strength," European Committee for Standardization, Brussels, Belgium.

EN 317 (1993). "Particleboards and fiberboards, determination of swelling in thickness after immersion," European Committee for Standardization, Brussels, Belgium.

EN 319 (1993). "Particleboards and fiberboards, determination of tensile strength perpendicular to plane of the board," European Committee for Standardization, Brussels, Belgium.

Enayati, A., and Bezaatipour, A. (2000). "A study on the possibility of applying used sleepers as a raw material for particleboard manufacturing," Iranian Journal of Natural Resources 53(2), 141-154.

Esmailpour, A., Taghiyari, H. R., Nouri, P., and Jahangiri, A. (2017). "Fire-retarding properties of nano-wollastonite in particleboard," Fire and Materials 42, 306-315. DOI: $10.1002 /$ fam.2493

ISO 11925-2 (2002). "Reaction to fire tests - Ignitability of building products subjected to direct impingement of flame - Part 2: Single-flame source test," International Organization for Standardization, Geneva, Switzerland.

Kasim, J., Ahmad, A. J. H. J., Harun, J., Ashari, Z. A. B. D., Mohmod, L., and Yusof, N. M. (2001). "Properties of particleboard manufactured from commonly utilized Malaysian bamboo (Gigantochloa scortechinii)," Pertanika Journal of Tropical Agricultural Science 24(2), 151-157.

Nacar, A., Hiziroglu, S., and Kalaycioglu, H. (2005). "Some of the properties of particleboard panels made from eucalyptus," American Journal of Applied Sciences 5-8.

Pan, Z., Zheng, Y., Zhang, R., and Jenkins, B. M. (2007). "Physical properties of thin particleboard made from saline eucalyptus," Industrial Crops and Products 26(2), 185-194. DOI: 10.1016/j.indcrop.2007.03.006

Tabarsa, T., Amousa, F., and Khazaeian, A. A. G. H. (2008). "Investigation on physical and mechanical properties of cement bonded particleboard manufactured from recycled railroad sleepers," Journal of Agricultural Sciences and Natural Resources 15(3), 168-175.

Article submitted: July 13, 2021; Peer review completed: August 28, 2021; Revised version received and accepted: August 29, 2021; Published: August 31, 2021.

DOI: 10.15376/biores.16.4.6984-6992 